\title{
The Study of the Construction and the Practice of Digital Campus in Sports University
}

\author{
WANG Shuntang ${ }^{1, a}$ \\ 1 Sport Information Technology Department, Shenyang Sport University, \\ Liaoning, China
}

\begin{abstract}
By adopting Literature research method, questionnaire method, logic analysis method and mathematical statistics method in exploring the theory and practice of digital campus construction in physical education institution under information technology environment; taking guiding and referencing effect in informational construction development in physical education institution. The result demonstrates that the construction of Campus Network (NC) provides supporting platform for improving PE education quality and education reformation; while the construction of multi-media classroom provides necessary hardware guarantee for informational education; establishing comprehensively functional and convenient and practical informational software platform is the key step; enrich the source of PE education, promote the construction of informational education source, promote teachers' informational competency, promote the level of coursewares and applications in class.
\end{abstract}

\section{Construcation of ampus Network (NC) provides supporting platform for improving PE education quality and education re-formation}

The construction of campus network is an important project in implement informatization in PE institutions; it is great move in deepening PE education reformation in new period, and improving the quality of education in PE education. The construction of campus network provides supporting platform for the structural adjustment in PE institution's professions, construction of coursework materials and resource sharing, reformation and innovation between practical teaching and training, construction of teacher teams and the multi-demands of quality monitoring system, promoting the quality of PE education.

Shenyang Sport University's network framework connecting to individual's desktop via trillions of Mbps. It is compatible to both IPv6 and IPv4 protocol. It is divided into three layers, Core Layer, Merging layer and Input layer.

The network between merging layer and core layer is using flow load sharing upstream. It fully ensures the availability of high bandwidth and high reliability of traffic grooming. Connecting to Chinese internet with bandwidth of $100 \mathrm{M}$, while $10 \mathrm{M}$ to education network. Campus Network is available 24/7, which provides

\footnotetext{
${ }^{\mathrm{a}}$ Corresponding author: tigeryuwang@sina.com
}

services for internet information exchange, online education, education management and administration management.

Campus' intranet constructs platforms for online course resources. Our faculty has 12 quality course in province level, 13 quality course in faculty level and 2 key courses in supporting (including course status, course content, synopsis, scripts, courseware and exercises), which are all available in our platform and provide convenience for teaching and self-studying.

Our Library intranet, with bandwidth of $1000 \mathrm{M}$ and imported advanced document information management integrating system, has enforced integration with purchasing, cataloging, flowing, indexing, reading and management. Besides, via the connection between campus network and internet it ensured the obtaining and using of network resources for all teachers and students.

\section{Constructionof multi-media classroom provides necessary hardware guarantee for informational education}

Multi-media education has been applied in Shenyang Sport University extensively. In accordance with the benchmark of first-class in the nation and well-known in the world, Shenyang Sport University provides multimedia classrooms for natatorium, basketball gymnasium, badminton and table tennis gymnasium, aerobics 
gymnasium, martial gymnasium, tennis court, volleyball court and athletics gymnasium. In order to solid the evaluation achievements, under the circumstance of tight budget, Shenyang Sport University built 11 more multimedia classrooms based on current 43 of them. Current the average of seat number per person in university is 0.72. In total 7414 students can have class in multi-media classrooms in all subjects. Network is connecting each individual multi-media classroom into every gymnasium. The intranet covers whole campus; broadband is connected into every single building, library, gymnasium, student activity centre, student dormitory and international communication centre. The number of wiring points is reaching 8,000 . Thus, we can say we are having a network multi-media global village in which all classrooms and gymnasiums are connected into our nation, into the whole world.

Table1 Number of seats in multi-media classroom per hundred students

\begin{tabular}{|c|c|c|c|c|}
\hline \multirow{2}{*}{ Year } & \multicolumn{2}{|c|}{$\begin{array}{c}\text { Multi-Media } \\
\text { Classroom }\end{array}$} & $\begin{array}{c}\text { Full time } \\
\text { students }\end{array}$ & $\begin{array}{c}\text { Number of seats } \\
\text { per 100 } \\
\text { students }\end{array}$ \\
\cline { 2 - 4 } & Number & Seats & & 26.20 \\
\hline $2004-2005$ & 14 & 1540 & 5877 & 24.75 \\
\hline $2005-2006$ & 14 & 1540 & 6222 & 66.90 \\
\hline $2006-2007$ & 50 & 4410 & 6592 & 72.04 \\
\hline $2007-2008$ & 61 & 5341 & 7414 & \\
\hline
\end{tabular}

\section{Enhance in training teachers'} conscience and ability in information technology. Through the procedure of making courseware, we created well information technology environment.

Information conscience and information talent's cultivation is the premise of whole construction. Information conscience, which pointing out the time we are living with today, is the one treating information technology as a sign of the time; is the one with global sharing and opening.

Teachers need know how to establish proper teaching method to fit the selection of information technology; cultivating students' competency in information technology; using the combination of information technology and courses in exploring; and using information technology sources to cultivate students' information technology knowledge, make them can use IT to obtain, evaluate and analysis demanded information; making student able to develop and pass information, and by using computer and other information technology, have the conscience and positive attitude in solving problems in teaching; from technical ground, it can provide students the abilities of searching, identification, screening and utilizing information technology, and the skills of using information technology in teaching.

Therefore, we enhanced the training to our teacher staff in multi-media technology's using and application. Since 2004, we have held 25 lectures about how to use multimedia courseware. More than 530 staff got trained. By incentive and encourage teachers to develop and use courseware in classroom, we held 5 times multi-media courseware competitions. The using of multi-media and other modern teaching methods dramatically improved the quality of teaching.

\section{$4 \quad$ Establishing comprehensively functional and convenient and practical informational software platform is the key step}

The utilizing and construction for education resources is the key content in university information and also is the part needs most attention and investment. As above table, the design and development of software has to be based on the information analysis of whole campus system. The software on campus network just likes cars on highway, needs to be stable, convenience and functional.

\subsection{Set up online course platform, providing convenience for students' self-study and teacher having lectures.}

In order to satisfy the need of assistant education of our theory course, we opened online course management system. By using this system, teachers can post the relevant materials in intranet. So far there are 30 subjects available online, which provide great convenience for lessoning and post study.

\subsection{Designing and developing sport video data bank, provides comprehensive resources for graduate education.}

Network data bank system has been constructed since 2004. It is base on the sports video materials, including courseware, documents and other kinds of educational martial platforms. This data bank has all kinds of sports video like coaching, games, references and material etc, which contain more than 1,100 hours video. Through media stream it could allow 100 people watching videos online simultaneously. The total size of online material is 4TB.

\subsection{Develop quality course management system, set up graduate excellent course platform}

This system is a course management system which has been in service since 2006. Now this system has 29 
province-level and university-level quality courses. By using this system, each teaching and research section can apply and maintain their quality course individually. This system provides great support and help for applying quality course. Besides, teachers can prepare and teaching; and students can learn these courses at anywhere.4.4

\subsection{Student information management system.}

This system is proper designed and fully functional. It is user-friendly and suitable for managing complex student information.

\subsection{Establishing student registration searching system}

Development centre designed this system by them own. This system has 10 functions, which not only relief the workload for student department but also make managing student orderly and efficient.

\section{6 working automation system}

This module has advanced technology, strong function and user-friendly manipulation. It saves huge cost in office work; and has strong function, applicability, security and expandability. This automation system improves the efficiency greatly in education management.

At the meanwhile, we set up websites and videos in Olympic knowledge and Tang Dynasty poetries etc. It provides massive healthy and positive video materials, which set the stage for enriching students' cultural life and improving students' cultural competency.

In conclusion, the construction of information technology environment is a long and tough project. It needs all our engagements and sustainability. Through resources allocation and process allocation, by the help of advanced information technology it could improve the quality and efficiency of education more efficiently; also it could cultivate students' ability and attitude in mastering study method in information technology time and having well information competency and the concept of study for ever. We should fully utilize multimedia network and combine it with our education process to reach the level of perfect integration.

\section{References}

1. Xinheng Wan, chief editor, Informationised campus: University revolution. Beijing University Press.

2. Zhiting Zhu, Education Informatization: high ground of Education technology. "China Audio-visual Education" 2001,(2)

3. Wenguang Li, Kaicheng Yang, Modern education technology concept under Information technology environment, "China Audio-visual Education" 2001, (2)
4. Derong Fu, The purpose, content and signiciance of education informatization. Education Technology Research, 2000,(4)

5. Yu Wei, chief editor, Implement the strategy of developing the country through science and education, speed up the construction of education informatization. China Central Radio and TV University Press, December 1999

6. Xinmin Sang. Information Revolution: The third milestone of human cultural education development. Shanghai Education, 1999 (3) (4) 